\title{
Vitrectomy in Endophthalmitis
}

\author{
Kapil Bhatia, Avinash Pathengay and Manav Khera \\ Retina Vitreous Services, L.V. Prasad Eye Institute, \\ GMR Varalakshmi Campus, Visakhapatnam \\ India
}

\section{Introduction}

Endophthalmitis is a severe, purulent intraocular inflammation of the intraocular cavities (i.e. the aqueous or vitreous humor) usually caused by infection. Endophthalmitis can be exogenous or endogenous.

Exogenous is caused by trauma or surgery (most commonly cataract extraction).

Approximately 70 percent of cases occur as a direct complication of intraocular surgery. Such post-operative endophthalmitis may be acute (presenting within 6 weeks of surgery) or chronic. Incidence of acute endophthalmitis following cataract extraction have been reported between $0.072 \%$ and $0.13 \%$ in various studies. ${ }^{1-4}$ The most common infecting organisms following cataract extraction are the coagulase-negative Staphylococcus spp., especially S. epidermidis.5,6

Endogenous (metastatic) endophthalmitis is caused by organisms reaching the eye via blood stream. In endogenous endophthalmitis, blood-borne organisms permeate the blood-ocular barrier either by direct invasion (e.g. septic emboli) or by changes in vascular endothelium caused by substrates released during infection. Destruction of intraocular tissues may be due to direct invasion by the organism and/or from inflammatory mediators of the immune response. It is seen in patients in whom body immunity is compromised e.g. chronic alcoholics, HIV patients, malignancy, renal transplant patients.

The management of endophthalmitis revolves around intense medical treatment and surgical intervention, with salvaging the eye and vision as primary aim (Table 1). Diagnosis and intensive treatment at the earliest possible time is essential. The timing is controversial and needs surgeon's judgment regarding immediate or delayed surgical intervention taking into account the risk and benefit to the patient (Table 2).

\section{Endophthalmitis Vitrectomy Study (EVS)}

Before the EVS, there were widely divergent opinions regarding the role of vitrectomy in endophthalmitis management, ranging from vitrectomy for all endophthalmitis cases to the use of vitrectomy for only the most severe cases with greater inflammation, worse visual acuity, and more rapid onset. Great strides were made for post cataract endophthalmitis with the execution of the prospective Endophthalmitis Vitrectomy Study (EVS) in the 1990s 


\section{Aim's of management}

- Kill the organism;

- Remove the inflammatory debris from the vitreous cavity

- Block the inflammatory cascade and its effects on the retina

- Treat the complications of the infection

Table 1. Summarizes the aims of management in endophthalmitis.

Immediate vitrectomy:

1. Obtains early sample for vitreous culture and to start specific treatment.

2. Clears ocular media to assess disease

severity and treatment response.

3. Removes toxic products/ vitreous scaffold for the formation of scar tissue as also the vitreous membranes which could lead to tractional retinal detachment.

4. Reduces bacterial load

5. Intravitreal antibiotics at the end of procedure.

6. Increases the antibiotics concentration in the eye. It also facilitates better diffusion and penetration of antibiotics as they are delivered directly to the infected site during vitrectomy.

7. Increases retinal oxygenization

8. Reduces the incidence and severity of retinal, especially macular, complications.
Delayed vitrectomy:

1. Easier to operate on a non inflamed eye

2. Tissue is less friable

3. Visualization is better

Table 2. Denotes the advantages of performing immediate vitrectomy over delayed vitrectomy in endophthalmitis.

to lay the guidelines for the timings of vitrectomy. ${ }^{7}$ The EVS evaluated the role of immediate pars plana vitrectomy versus intraocular antibiotic injection (TAP) and systemic antibiotics in the treatment of acute postoperative endophthalmitis. Acute postoperative endophthalmitis (presenting within 6 weeks) and secondary IOL implantation patients who were having an initial visual acuity between 20/50 and light perception, and had a view sufficient to perform a vitrectomy were included in the study. 420 patients were randomized to immediate initial TAP or vitrectomy. There was no difference in final visual outcomes in patients who underwent initial TAP or vitrectomy if presenting visual acuity was better than light perception. However, in patients presenting with light perception vision, those who underwent initial vitrectomy were 3 times more likely to achieve $20 / 40$ vision or better, twice as likely to maintain 20/100 vision or better, and had a nearly $50 \%$ reduction in the risk of severe visual loss $(<5 / 200)$, compared to patients who underwent TAP. No long-term difference occurred in media clarity between the treatment groups. 


\section{Pitfalls of EVS}

Although EVS study did give us first insight and guidelines, but there were various pitfalls present in the study itself. Since the EVS specifically excluded patients with postoperative endophthalmitis who underwent any procedure other than cataract surgery, results cannot be generalized to every endophthalmitis. In patients with conjunctival filtering blebassociated endophthalmitis, earlier vitrectomy is preferred because of more profound inflammation and the increased probability of more virulent organisms. Further traumatic endophthalmitis (especially associated with intraocular foreign body) presents with intense inflammation and if vitrectomy is not done early, it can lead to loss of the eye. Chronic postoperative endophthalmitis (caused by P.acne or fungus) has been associated with high rates of persistent inflammation. Vitrectomy with special attention to either partial or total capsular bag excision with or without IOL removal has been reported effective in eradicating inflammation as compared to TAP alone. Further newer generations systemic antibiotics can achieve good concentration inside the eye, and help in reducing the infection and achieving having good outcome. Technological advancements in vitreoretinal surgery since EVS have minimized the risks associated with vitrectomy favoring the initial use of vitrectomy in less severe cases also.

\section{Procedure}

Before starting surgical intervention, necessary instruments and drugs should be ready. (Table 3)

\begin{tabular}{|c|c|c|}
\hline - Instruments: & - Disposables: & - Medication: \\
\hline - Eye speculum & - Surgical drape & - 0.5\% Bupivacaine \\
\hline - Forceps & - Sterile surgical gloves & - 2\% lidocaine \\
\hline - Irrigation cannula & - 10\% povidone iodine swabs & - 150 IE Hyaluronidase \\
\hline - Corneo-scleral scissors & $-5 \%$ povidone iodine solution & $\begin{array}{l}-0.1 \text { cc Cetazidime }(22.5 \\
\mathrm{mg} / \mathrm{ml})\end{array}$ \\
\hline $\begin{array}{l}\text { - Vitrectome hand piece and } \\
\text { unit }\end{array}$ & - Three plastic cups & $\begin{array}{l}-0.1 \mathrm{cc} \text { Vancomycin }(10 \\
\mathrm{mg} / \mathrm{ml})\end{array}$ \\
\hline \multirow[t]{8}{*}{ - Barraquer forceps } & - One syringe $(6.0 \mathrm{cc})$ & $\begin{array}{l}\text { - } 0.1 \mathrm{cc} \text { Dexamethasone }(4 \\
\mathrm{mg} / \mathrm{ml})\end{array}$ \\
\hline & - Four syringes $(1.0 \mathrm{cc})$ & \\
\hline & - Cotton tip applicators & \\
\hline & - Three 30-gauge needles & \\
\hline & $\begin{array}{l}\text { - Three sterile caps for } \\
\text { syringes }\end{array}$ & \\
\hline & - $4 \times 4$-cm sterile cotton pads & \\
\hline & $\begin{array}{l}\text { - 23-gauge microvitreoretinal } \\
\text { blade }\end{array}$ & \\
\hline & - Eye pad and tape & \\
\hline
\end{tabular}

Table 3. Signifies equipment required for the management of endophthalmitis 


\section{Vitreous tap}

This procedure is preferably done under peribulbar anaesthesia using $2 \%$ lignocaine and/or $0.5 \%$ bupivacaine. As with routine surgery, eye has to be prepared using povidone-iodine scrub followed by sterile drape. Vitreous tap can be done either with a needle attached to a syringe or using the vitreous cutter.

A 5 cc syringe and small gauge needle (23-26G) is preferred for the aspiration. A 23 gauge butterfly needle can also be used for this purpose. The needle is inserted approximately 3$4 \mathrm{~mm}$ (3mm for aphakic, $3.5 \mathrm{~mm}$ for pseudophakic and $4 \mathrm{~mm}$ for phakic patients) from the limbus into the mid vitreous cavity. Gentle aspiration is applied and $0.2-0.3 \mathrm{ml}$ of fluid is aspirated. If vitreous is not aspirated, the needle tip can be carefully moved in an attempt to locate a pocket of liquid vitreous. If after several attempts a vitreous specimen cannot be obtained the procedure should be terminated as suction can lead to iatrogenic retinal tears formation and subsequent retinal detachment.In such kind of cases one could use vitreous cutter to tap the vitreous. Intraocular antibiotics can be injected at the same sitting. Vancomycin $(1 \mathrm{mg}$ in $0.1 \mathrm{ml})$, and ceftazidime $(2.25 \mathrm{mg}$ in $0.1 \mathrm{ml})$ are the preferred drugs initially till the final microbiology report is available. Doses of various intravitreal antibiotic chart should be prepared and should be pasted in operation theatre as doses are confusing, and slight mistake in making can lead to adverse events (e.g. toxicity). Common intravitreal antibiotics doses and their mechanism of action have been described in (Table 4).

\section{Vitrectomy}

The surgical technique of vitrectomy is similar to the standard three-port vitrectomy with few exceptions. Securing the infusion cannula correctly is very important and its visualization through an inflammed choroid and hazy media can be a difficult thing. A longer infusion cannula (6-mm cannula), is generally recommended in these situations. If cannula is still not visible then a good alternative is to use the hand held infusion cannula and clear vitreous exudates with the cutter till the regular cannula is visible through the pupil. If the epithelium is edematous, its removal may be necessary. Scraping the epithelium can increases the visibility and thus increases the success rate of the surgery. If the stroma also has significant edema, pressing a dry sponge against it, or using topical highconcentration glucose may increase visibility. The anterior chamber often contains hypopyon and exudative membrane which interferes with adequate visualization. In pseudophakic patients a 26-gauge instrument, such as, a hypodermic needle could be introduced through the limbus to clear the hypopyon and any inflammatory membrane without explantation of the IOL or anterior chamber maintainer can be used and inflammatory material over IOL can be aspirated to make visualization better. Vitreous aspirate should be the first step of the surgery before starting the infusion to get an undiluted sample for culture. Vitreous sample is collected by short tubing attached to the suction port of the vitrectomy probe. The suction is operated manually by syringe attached to the tubing. Infusion fluid bottle should be at a low height. Care should be taken not to cause too much hypotony while taking vitreous aspirate and as soon as biopsy is obtained, infusion should be switched on, and suction should be very slow so as not to cause any inadvertent traction leading to break formation. The aim of vitrectomy in endophthalmitis is 


\begin{tabular}{|c|c|c|}
\hline ANTIBIOTICS & DOSE & MECHANISM OF ACTION \\
\hline Amikacin & $0.4 \mathrm{mg} / 0.1 \mathrm{ml}$ & $\begin{array}{l}\text { Inhibit protein synthesis by binding to the } 30 \mathrm{~S} \\
\text { rRNA molecule of the bacterial ribosome }\end{array}$ \\
\hline Kanamycin & $0.5 \mathrm{mg} / 0.1 \mathrm{ml}$ & $\begin{array}{l}\text { Inhibit protein synthesis by binding to the } 30 S \\
\text { rRNA molecule of the bacterial ribosome }\end{array}$ \\
\hline Tobramycin & $0.4 \mathrm{mg} / 0.1 \mathrm{ml}$ & $\begin{array}{l}\text { Inhibit protein synthesis by binding to the } 30 \mathrm{~S} \\
\text { rRNA molecule of the bacterial ribosome }\end{array}$ \\
\hline Vancomycin & $1.0 \mathrm{mg} / \mathrm{o} .1 \mathrm{ml}$ & $\begin{array}{l}\text { Inhibit protein synthesis by binding to the } 30 S \\
\text { rRNA molecule of the bacterial ribosome }\end{array}$ \\
\hline Ampicillin & $5.0 \mathrm{mg} / 0.1 \mathrm{ml}$ & $\begin{array}{l}\text { Inhibition of bacterial cell wall synthesis by } \\
\text { preventing the cross linking of peptides on the } \\
\text { mucosaccharide chains }\end{array}$ \\
\hline Carbenicillin & $2.0 \mathrm{mg} / 0.1 \mathrm{ml}$ & $\begin{array}{l}\text { Inhibition of bacterial cell wall synthesis by } \\
\text { preventing the cross linking of peptides on the } \\
\text { mucosaccharide chains }\end{array}$ \\
\hline Methicillin & $2.0 \mathrm{mg} / 0.1 \mathrm{ml}$ & $\begin{array}{l}\text { Inhibition of bacterial cell wall synthesis by } \\
\text { preventing the cross linking of peptides on the } \\
\text { mucosaccharide chains }\end{array}$ \\
\hline Erythromycin & $0.5 \mathrm{mg} / 0.1 \mathrm{ml}$ & $\begin{array}{l}\text { Inhibit protein synthesis by binding to the } 23 S \\
\text { rRNA molecule (in the } 50 \text { S subunit) of the bacterial } \\
\text { ribosome blocking the exit of the growing peptide } \\
\text { chain }\end{array}$ \\
\hline Gentamicin & $0.2 \mathrm{mg} / 0.1 \mathrm{ml}$ & $\begin{array}{l}\text { Inhibit protein synthesis by binding to the } 30 \mathrm{~S} \\
\text { rRNA molecule of the bacterial ribosome }\end{array}$ \\
\hline Cefazoline & $2.0 \mathrm{mg} / 0.1 \mathrm{ml}$ & $\begin{array}{l}\text { Inhibition of bacterial cell wall synthesis by } \\
\text { preventing the cross linking of peptides on the } \\
\text { mucosaccharide chains }\end{array}$ \\
\hline Ceftazidime & $2.25 \mathrm{mg} / 0.1 \mathrm{ml}$ & $\begin{array}{l}\text { Inhibition of bacterial cell wall synthesis by } \\
\text { preventing the cross linking of peptides on the } \\
\text { mucosaccharide chains }\end{array}$ \\
\hline Imipenum & $0.05 \mathrm{mg} / 0.1 \mathrm{ml}$ & $\begin{array}{l}\text { Inhibition of synthesis of the peptidoglycan layer of } \\
\text { bacterial cell walls }\end{array}$ \\
\hline Tazobactum & $2.25 \mathrm{mg} / 0.1 \mathrm{ml}$ & Inhibition of bacterial cell wall synthesis \\
\hline \multicolumn{3}{|l|}{ ANTIFUNGALS } \\
\hline Amphotericin B & $0.5 \mathrm{mg} / 0.1 \mathrm{ml}$ & $\begin{array}{l}\text { Associates with ergosterol forming a } \\
\text { transmembrane channel that leads to monovalent } \\
\text { ion }\left(\mathrm{K}^{+}, \mathrm{Na}^{+}, \mathrm{H}^{+} \text {and } \mathrm{Cl}^{-}\right) \text {leakage }\end{array}$ \\
\hline Voriconazole & $0.05 \mathrm{mg} / 0.1 \mathrm{ml}$ & $\begin{array}{l}\text { Inhibition of fungal-cytochrome P-450-mediated } 14 \\
\text { alpha- lanosterol demethylation, leading to an } \\
\text { accumulation of } 14 \text { alpha-methyl sterols which } \\
\text { results in loss of ergosterol in the cell wall }\end{array}$ \\
\hline
\end{tabular}

Table 4. Summarizes the dose of intravitreal antimicrobial agents and mechanism of actions of these drugs used in the management of endophthalmitis. 
only to perform a "core" vitrectomy. There should be minimal traction on the inflamed and friable retina. To avoid unnecessary traction, vitrectomy should be performed with low suction and high cut rate. PVD (posterior vitreous detachment) induction should be avoided as it can lead to traction and can lead to break formation leading to rhegmatogenous retinal detachment. IOL explantation is not necessary in all the cases of pseudophakic endophthalmitis. ${ }^{8,9}$ Explantation of the IOL is mostly necessary in fungal endophthalmitis and in $P$. acnes endophthalmitis, however one should try to preserve IOL as far as possible and perform a generous capsulotomy, either to retain or exchange the IOL and to inject intraocular antibiotic near the remaining part of the capsular bag. ${ }^{10}$ IOL explantation should be reserved as a last option.

\section{Endophthalmitis in phakic patients}

The above mentioned procedure holds good if patients is aphakic or having intraocular lens (IOL) implanted. Endophthalmitis in phakic patients presents with difficult situation (e.g. traumatic or endogenous endophthalmitis). Lens can be clear with major involvement of posterior segment or lens can be involved (lens abscess). Preserving the lens has the advantage of preserving the natural lens, and it increases the half-life of intraocular antibiotics. ${ }^{32}$ In a study by Huang et al, authors were able to control the infections in all the eyes (12 eyes) without removing the natural lens. ${ }^{33}$ Six of 12 eyes achieved $20 / 80$ or better visual acuity with an average follow-up time of 13 months. Six of eight eyes treated with pars plana vitrectomy and intraocular antibiotic injection achieved this level of visual acuity in contrast to none of four eyes treated with only intraocular antibiotic injection. ${ }^{33}$ If infection is severe and media is hazy because of lens, one should not be hesitant to remove lens, so as to have better visualization to complete vitrectomy and achieve good visual outcome. IOL placement can be done as a secondary procedure at later date once infection is well controlled. However one should try to preserve lens as far as possible.

\section{Extent of vitrectomy}

There is a variable consensus on the extent of the vitrectomy. According to the EVS study, only core vitrectomy should be done and posterior vitreous detachment (PVD) should be avoided as far as possible, as retina is inflammed and friable and there are high chances of retinal break formation. Core vitrectomy comprises the removal of anterior and central vitreous first, followed by posterior central vitreous. No attempt is made to enter vitreous base. No posterior hyaloid cleaning is done. Core vitrectomy is only done in central area and peripheral vitrectomy should be avoided. End point of vitrectomy is either when red glow is visible or disc with $1^{\text {st }}$ order vessels are visible. Intravitreal antibiotics are injected at the end of the procedure. As opposed to conservative vitrectomy (recommended by EVS and followed mostly), induction of PVD and little more aggressive vitrectomy was advocated in complete and early vitrectomy for endophthalmitis (CEVE). ${ }^{11}$ Authors in their series of 47 consecutive postoperative endophthalmitis patients found statistically significantly better anatomical and functional results with CEVE than in either management arm in the EVS. The authors attribute this improvement to vitrectomy being early and complete, and to its being the primary line of treatment, rather than being applied as a last resort. ${ }^{11}$ According to author PVD induction should only be done at 
posterior pole over non-necrotic area. PVD should not be attempted aggressively or should not be extended beyond equator, as there are high chances of teat formation with subsequent retinal detachment. Further posterior exudates over the surface of retina can be aspirated by soft tip flute needle. PVD induction will have direct access of antibiotics to retinal surfaces and removes posterior vitreous scaffold for infection, leading to early recovery.

During vitrectomy surgeon should be extremely careful to cut anything as there are several vitreous layers and membranes can be present and sometimes it is very difficult to differentiate them from the retina esp. when there are streaks of blood among the layers, giving the appearance of a detached retina. Further retina can become necrotic in endophthalmitis leading to white avascular appearance simulating vitreous layers, and even on cutting it does not bleed. A less experienced or careful surgeon may remove large area of the retina before realizing it. To avoid this complication, surgeon should not cut any membrane without visualization. Vitrectomy should be started from behind the lens and then slowly one should advance towards the retina. If there is doubt regarding the structures, its better to do vitrectomy in nasal quadrant to avoid inadvertent injury to the fovea. If still it is not possible to differentiate the retina from the vitreous, its better to do very minimal vitrectomy and plan repeat surgery later once the media clarity improves a little, rather than doing more harm to the patient. Many a time's visibility is the major concern in performing vitrectomy and extent of vitrectomy depends entirely upon the visualization.. There are several options:

- Vitrectomy may be performed in a limited fashion, ("Proportional pars plana vitrectomy" [PPPV], a term coined by R. Morris). ${ }^{12}$ It is always better to perform vitreous tap with limited core vitrectomy rather than inflicting severe damage because of poor visualization.

- A temporary keratoprosthesis (TKP) can be placed followed by implantation of donor cornea at the conclusion of surgery. If no donor cornea is available, even the original corneal button may be temporarily reused.

- An endoscope may be utilized. But considerable experience is required on surgeon's part and availability is also the major problem.

Surgical procedure mentioned above cannot be applied to all the cases of endophthalmitis, as, post-traumatic and bleb related endophthalmitis are very difficult to manage and chronic endophthalmitis presents a very different clinical challenge to the clinician. So surgical modifications have to be adopted based on clinical presentation.

\section{Acute-onset postoperative endophthalmitis}

Acute postoperative endophthalmitis usually presents within 6 weeks of the surgery. It can present after any intraocular surgery, but it is most common after cataract surgery. Most common organism implicated is coagulase-negative staphylococci, but Staphylococcus aureus, the Streptococcus species, and gram-negative organisms can also cause postoperative endophthalmitis. As EVS study was done for post-operative endophthalmitis, so the results can be safely followed here. Early cases of endophthalmitis can be treated with vitreous TAP along with intravitreal antibiotics, but for severe cases PPV is the treatment of choice (figure $1 \mathrm{a}, \mathrm{b})$. Presenting visual acuity was the single most important factor in EVS predicting the 


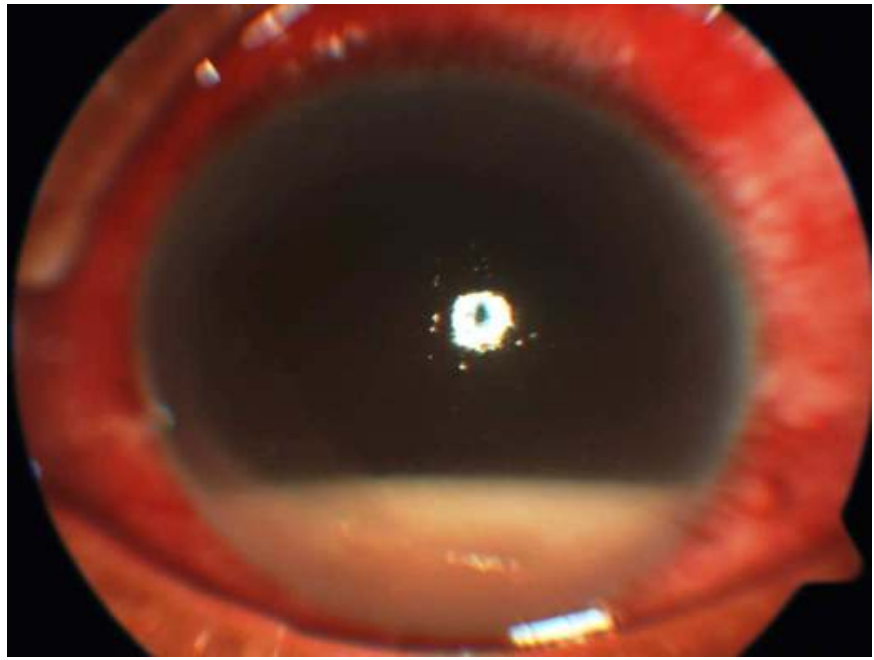

a.

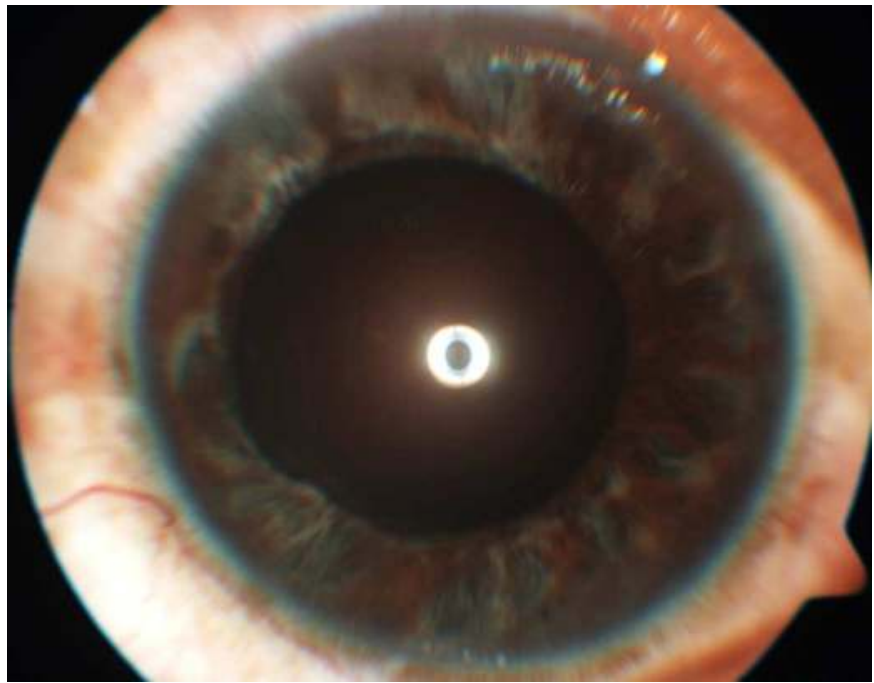

b.

Fig. 1. Photographs of the left eye of $55 \mathrm{yr}$ male presenting with acute endophthalmitis of bacterial origin a. Presenting VA: HM, IOP: $18 \mathrm{mmHg}$. Treatment: pars plana vitrectomy with intravitreal Vancomycin, Ceftazidime, and Dexamethasone. b. At 3 months VA:20/40, IOP:14 mmHg.

final visual acuity. In EVS, $23 \%$ of patients with light perception acuity achieved 20/40 or better final acuity, compared with $64 \%$ of patients who had hand motions or better acuity. This data signifies the need for early treatment before severe visual loss happens (regardless whether TAP or vitrectomy is done). Once patient presents with severe visual loss, vitrectomy has better visual outcome and is the treatment of choice. Role of intravitreal 
steroid is controversial in these cases. Since $90 \%$ of these cases are caused by bacteria, so early steroid administration reduces the inflammation and increases the chances of visual recovery (figure $2 \mathrm{a}, \mathrm{b}$ ). In a prospective randomized clinical trial of 63 bacterial endophthalmitis cases Das et al, found that intravitreal dexamethasone reduces inflammation scores early in the course of treatment but had no independent influence on the final visual outcome. ${ }^{13}$ So the role of steroids is still controversial.

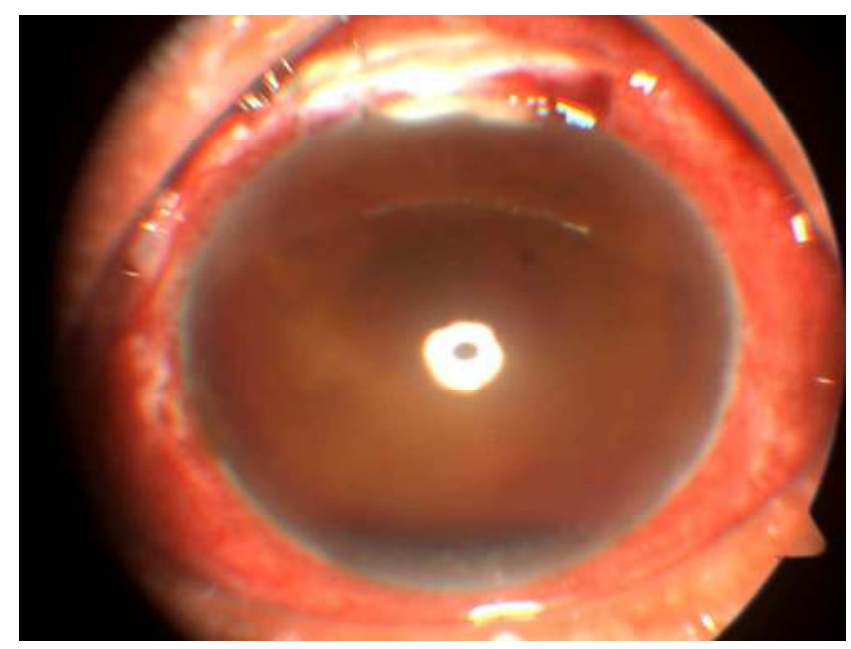

a.

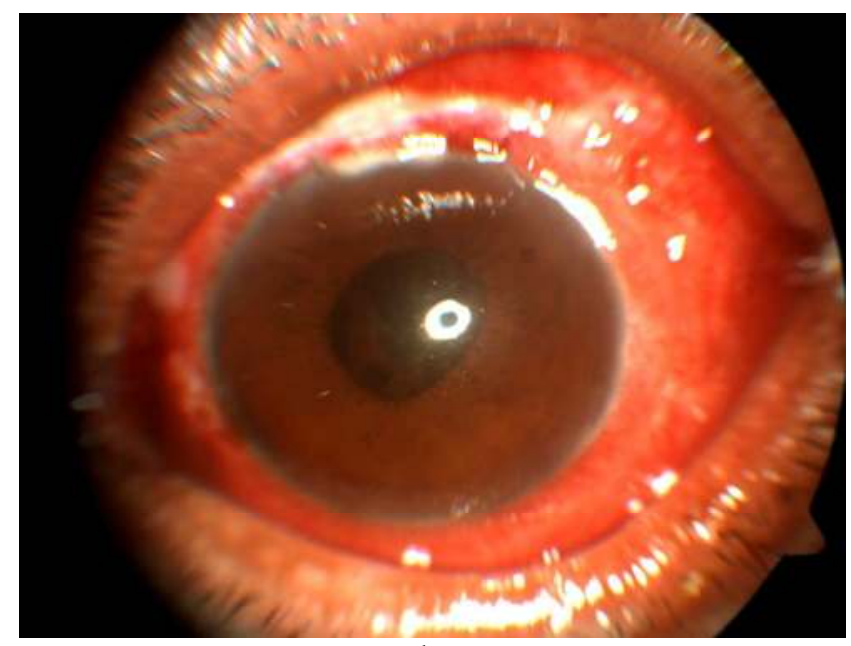

b.

Fig. 2. Photographs of the eye of $40 \mathrm{yr}$ male presenting with acute postoperative endophthalmitis with scleral tunnel infiltrate (culture negative) a. Presenting VA: HM. Treatment: pars plana vitrectomy with intravitreal Vancomycin, Ceftazidime, Dexamethasone, tunnel resuturing. Patient received $4 \mathrm{IOAB}+$ dexamethasone injections after initial PPV. b. At 3 months VA:20/60. 


\section{Delayed-onset or chronic postoperative endophthalmitis}

Endophthalmitis patients presenting after 6 weeks (months to year), are included in chronic endophthalmitis. They present not only with diagnostic challenge, but their management is vastly different from acute onset counterpart. Propionibacterium acnes, a gram-positive, anaerobic rod, is the most common organism causing chronic endophthalmitis. Characteristic feature of P.acne endophthalmitis is whitish capsular plaque (organisms mixed with residual lens cortex), which can be mistaken for posterior capsular opacification. Since organisms are residing inside capsular bag, simple vitrectomy with intravitreal antibiotics generally leads to inferior result with recurrence of infection. A pars plana vitrectomy and a central capsulectomy together with intravitreal antibiotics (vancomycin is the drug of choice) is generally recommended as the first line management. ${ }^{14-16}$ Vancomycin is injected into capsular bag at the end of the procedure. If infection is still not controlled; IOL removal along with complete bag removal is the treatment of choice. In clinically suspected fungal infections (2nd most common cause of chronic endophthalmitis) characterized by fluffy vitreous infiltrates with white snow ball like opacities, immediate injection of antifungal agents (intravitreal amphotericin B $5 \mu \mathrm{g}$ or voriconazole $100 \mathrm{ug}$ ), is recommended after vitrectomy. If still infection is not controlled, total capsulectomy and IOL removal should be considered. ${ }^{17,18}$

\section{Posttraumatic endophthalmitis}

In contrast to acute postoperative endophthalmitis, posttraumatic endophthalmitis carries worse prognosis (high severity of infection, polymicrobial etiology, associated pathologies e.g. IOFB, RD). Bacillus species, most commonly B. cereus, is the most common organism (cultured positivity $28 \%$ to $46 \%$ ). ${ }^{19}, 20$ Endophthalmitis caused by Bacillus species is progressive, and generally carries a poor visual prognosis, even after immediate vitrectomy. ${ }^{21-23}$ Traumatic endophthalmitis esp. associated with retained intraocular foreign body (IOFB) carries the worst prognosis. In one study 3.5\% patients with retained foreign bodies developed endophthalmitis when the primary surgical repair was accomplished within 24 hours of the injury compared with $13.4 \%$ patients in whom the primary surgical repair was delayed more than 24 hours. ${ }^{24}$ Further only $40.9 \%$ culture-positive cases achieved $20 / 400$ or better visual acuity necessitating the need for early vitrectomy and removal of IOFB. If retinal break or retinal detachment is also present, complete vitrectomy with endolaser of break with silicone oil injection is warranted to achieve good anatomical outcome.

\section{Endogenous endophthalmitis}

It is commonly seen in patients in whom body immunity is compromised e.g. chronic alcoholics, HIV patients, malignancy, renal transplant patients. Most common organisms implicated are bacteria or fungus (candida, aspergillus). The timing of and necessity for vitrectomy remains unclear in endogenous as compared with postoperative endophthalmitis. Vitrectomy will be more useful in posterior diffuse disease and severe disease (figure $3 a, b$ ). In cases of fungal endophthalmitis, vitrectomy provides a good specimen for microbiology and effectively reduces the number of organisms. It is also crucial to consider the overall status of these individuals, many of whom will be desperately 


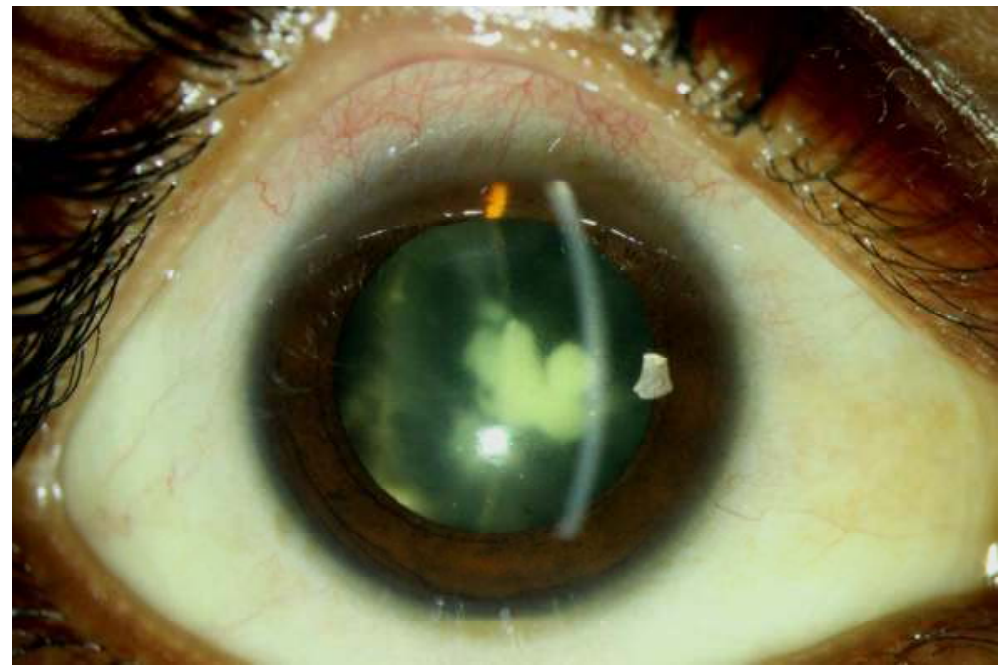

a.

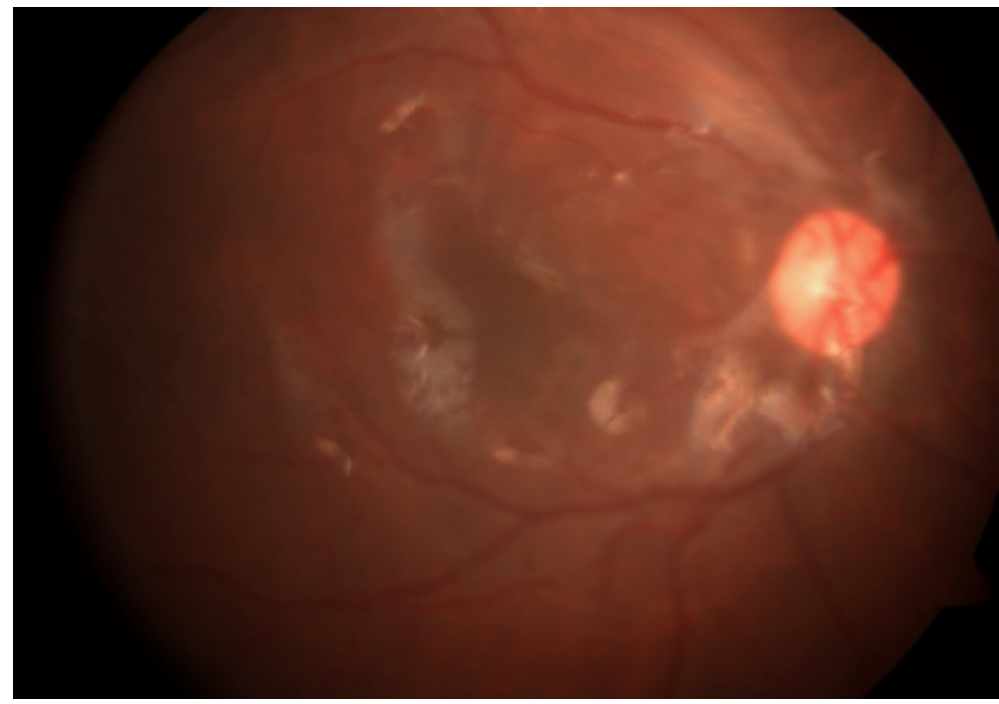

b.

Fig. 3. Photographs of the right eye of $22 \mathrm{yr}$ male presenting with acute endogenous endophthalmitis (gram negative bacilli) a. Presenting VA: PL PR ACCURATE. Treatment: pars plana vitrectomy with intravitreal Vancomycin, Ceftazidime, and Dexamethasone. Patient developed RD for which PPV+EL+SIO was done. b. At 3 months VA:20/30.

ill from systemic sepsis and anesthesia risk for surgery is very high. Despite aggressive antimicrobial therapy, most patients with endogenous endophthalmitis have a poor outcome. In a study from Singapore over a 4-year period, 17 of 32 affected eyes ended up with no light perception even after early surgical intervention. 25 


\section{Bleb associated endophthalmitis}

The organisms frequently involved in this type of endophthalmitis include streptococcal species and Haemophilus influenzae. These organisms liberate potent toxins and tissue damaging enzymes that may contribute to virulence of intraocular infection and associated intraocular inflammation. The treatment of infections with such organisms poses serious problems. Even if the intraocular spaces are sterilised with appropriate antibiotics, a significant amount of bacterial debris and potentially toxic products remain to account for treatment failure. Hence pars plana vitrectomy and intraocular antibiotics are considered as the first line of management. Inspite of early and aggressive approach, visual outcome is not satisfactory. Song et al in their series of post bleb related endophthalmitis found that patients who underwent prompt pars plana vitrectomy (PPV)generally had a worse final visual outcome when compared with the tap/inject group. ${ }^{26}$ Busbee et al however found contrasting results with regard to treatment modality in the 68 patients with bleb associated endophthalmitis. Patients who underwent PPV had a greater likelihood of retaining 20/100 vision or better at 12 months when compared with tap/inject ( $33 \%$ vs $13 \%, \mathrm{P}=0.09$ ). Significantly higher rates of no light perception (NLP) vision were also seen in patients with a positive culture or who underwent tap/inject as primary treatment indicating early need for the vitrectomy. ${ }^{27}$ Dexamethasone can be used as along with antibiotics, as it will reduce the inflammatory damage induced by toxins thereby limiting the visual loss. However final visual acuity was same in dexamethasone receiving endophthalmitis group as well as in other group not receiving the drug as reported in literature. ${ }^{13,27}$

A brief summarization regarding the treatment and outcome of these types of endophthalmitis is given below (Table 5).

\begin{tabular}{|l|l|l|l|l|l|}
\hline & $\begin{array}{l}\text { Acute Postop. } \\
\text { Endophthalmitis }\end{array}$ & $\begin{array}{l}\text { Delayed/Chronic } \\
\text { Postop. } \\
\text { Endophthalmitis }\end{array}$ & $\begin{array}{l}\text { Bleb Associated } \\
\text { Endophthalmitis }\end{array}$ & $\begin{array}{l}\text { Endogenous } \\
\text { Endophthalmitis }\end{array}$ & $\begin{array}{l}\text { Traumatic } \\
\text { Endophthalmitis }\end{array}$ \\
\hline $\begin{array}{l}\text { Causative } \\
\text { organism }\end{array}$ & $\begin{array}{l}\text { Coagulase } \\
\text { negative } \\
\text { Staphylococci }\end{array}$ & $\begin{array}{l}\text { P.Acne, Fungi, } \\
\text { Staphylococcus } \\
\text { epidermidis }\end{array}$ & $\begin{array}{l}\text { Streptococcus, } \\
\text { Hemophilus }\end{array}$ & $\begin{array}{l}\text { Bacteria, } \\
\text { Fungi }\end{array}$ & $\begin{array}{l}\text { Bacilli, } \\
\text { Fungi, } \\
\text { Mixed }\end{array}$ \\
\hline $\begin{array}{l}\text { Treatment } \\
\text { of } \\
\text { choice }\end{array}$ & PPV/TAP+IOAB & $\begin{array}{l}\text { PPV } \pm \text { IOL } \\
\text { explantation } \pm \\
\text { Capsular bag } \\
\text { removal + IOAB }\end{array}$ & PPV + IOAB & $\begin{array}{l}\text { PPV/TAP + } \\
\text { IOAB }\end{array}$ & $\begin{array}{l}\text { PPV+IOAB } \\
\pm \text { additional } \\
\text { procedure }\end{array}$ \\
\hline $\begin{array}{l}\text { Indications } \\
\text { of } \\
\text { vitrectomy }\end{array}$ & $\begin{array}{l}\text { Severe infection, } \\
\text { presenting vision } \\
\text { PL } \pm, \\
\text { worsening } \\
\text { clinical picture }\end{array}$ & $\begin{array}{l}\text { Recurrent } \\
\text { episodes, white } \\
\text { capsular plaque, } \\
\text { fungal } \\
\text { etiology }\end{array}$ & Mostly all cases & $\begin{array}{l}\text { Severe infection, } \\
\text { presenting } \\
\text { vision PL } \pm, \\
\text { worsening } \\
\text { clinical picture }\end{array}$ & $\begin{array}{l}\text { Mostly preferred } \\
\text { esp. associated } \\
\text { with IOFB, } \\
\text { suspected fungal } \\
\text { etiology }\end{array}$ \\
\hline Prognosis & $\begin{array}{l}\text { Depends on } \\
\text { initial visual } \\
\text { Acuity, organism } \\
\text { virulence }\end{array}$ & Variable & Poor & Poor & Poor \\
\hline
\end{tabular}

Table 5. Summarization of treatment option and prognosis of various types of endophthalmitis 


\section{Complications}

Vitrectomy procedure for endophthalmitis carries high complication rates because of several reasons. Various complications that commonly occur during vitrectomy are:

1. Retinal break: Breaks can occur as a normal complication, as a direct injury from an intravitreal instrument, or as a result of aggressive vitrectomy to induce PVD. The breaks can be surrounded with laser or silicone oil may be used.

2. Retinal Detachment: Retinal detachment can be rhegmatogenous (retinal break, surgical complication), tractional or exudative. Retina is very friable and necrotic in endophthalmitis, so chances of break formation with subsequent retinal detachment are very high.

3. Vitreous hemorrhage

4. Retinal toxicity from antibiotics

5. Phthisis bulbi

In the EVS, major adverse events included retinal detachment in 5\%, phthisis in 3\%. Compared with TAP, vitrectomy was associated with a slightly lower rate of complications. Retinal detachment and phthisis occurred in $2.7 \%$ and $2 \%$ of vitrectomy eyes, respectively, compared to $7 \%$ and $4 \%$ of TAP group. However incidence of late additional surgical procedure did not differ whether vitrectomy was performed or initial procedure was TAP. The incidence of late additional surgical procedures was $27 \%$ overall. ${ }^{31}$

\section{Role of introcular tamponade}

Routine endophthalmitis surgery does not require any tamponade. However tamponade is necessary if any complication happens. Retinal with subsequent retinal detachment requires long term tamponade. Silicone oil can be used in cases where retinal break formation or retinal detachment has occurred. Not only it provides a long term tamponade, but it also retards the infectious process, as bacteria do not grow in silicone oil. However one should try to remove as much vitreous possible before injecting oil. Further doses of intravitreal injections has to be reduced (in general half the normal dosage), as oil prolongs their halflife and if normal doses are injected there are high chances of retinal toxicity.

Finally vitrectomy for endophthalmitis can also be done using suturless ( 23 or 25 gauge) system. There appears to be a trend toward the use of smaller gauge vitrectomy systems. Possible advantages include shorter operating time, reduced post operative inflammation from sutures in an already inflamed eye, reduced incidence of post operative retinal tears and detachments. ${ }^{28}$ Hilton et al; have evaluated office based suturless pars plana vitrectomy for various diseases including endophthalmitis with good success. ${ }^{29}$

Tan et al, reviewed the outcomes of 23G vitrectomy in patients with postoperative endophthalmitis and found it to be a useful technique. There was no case of postoperative hypotony or wound leak. ${ }^{30}$

In summary vitrectomy helps in debulking of vitreous, allowing dispersion of intra-ocular antibiotics and facilitating clearing of the visual pathway. Microbiological diagnosis is best made by culture of vitreous aspirate. Therapeutic vitrectomy is reserved for severe cases, defined as vitreous inflammation severe enough to obstruct view of the posterior pole on 
indirect ophthalmoscopy, progressive inflammation despite initial antibiotic therapy, and/or cases that have not improved despite initial therapy. The need for additional procedures is a marker of more severe disease and is usually associated with worse visual outcomes. However, management of patients should be individualized and should be based on clinical judgment.

\section{References}

[1] Aaberg TM Jr, Flynn HW Jr, Schiffman J, Newton J. Nosocomial acute-onset postoperative endophthalmitis survey. A 10-yr review of incidence and outcomes. Ophthalmology. 1998;105:1004-10.

[2] Powe NR, Schein OD, Gieser SC, et al. Synthesis of the literature on visual acuity and complications after cataract extraction with intraocular lens implantation. Arch Ophthalmol. 1994;112:239-52.

[3] Javitt JC, Vitale S, Canner JK, et al. National outcomes of cataract extraction: endophthalmitis after inpatient surgery. Arch Ophthalmol. 1991;109:1085-9.

[4] Kattan HM, Flynn HW Jr, Pflugfelder SC, et al. Nosocomial endophthalmitis survey. Current incidence of infection after intraocular surgery. Ophthalmology. 1991;98:227-38.

[5] Han DP, Wisniewski SR, Wilson LA, et al. Spectrum and susceptibilities of microbiologic isolates in the Endophthalmitis Vitrectomy Study. Am J Ophthalmol. 1996;122:1-17

[6] Kunimoto DY, Das T, Sharma S, et al. Microbiologic spectrum and susceptibility of isolates: part I. Postoperative endophthalmitis. Endophthalmitis Research Group. Am J Ophthalmol. 1999;128:240-2.

[7] Endophthalmitis Vitrectomy Study Group: Results of the Endophthalmitis Vit- rectomy Study: a randomized trial of immediate vitrectomy and of intravenous antibiotics for the treatment of postoperative bacterial endophthalmitis. Arch Ophthalmol 1995;13:1479-1496.

[8] Driebe W, Mandelbaum S, Forster RK. Pseudophakic endophthalmitis: Diagnosis and management. Ophthalmology 1986;93:442-447.

[9] Hopen G, Mondino BJ, Kozy D, et al. Intraocular lenses and experimental bacterial endophthalmitis. Am J Ophthalmol 1982;94:402-407.

[10] Benson WE. Current management of postsurgical endophthalmitis. In:The Year book of Ophthalmology, Laibson PR, ed. Chicago, Year Book Medical Publishers Inc., 1989, pp. 181-184.

[11] Kuhn F, Gini G. Complete and early vitrectomy for endophthalmitis (CEVE) as today's alternative to the Endophthalmitis vitrectomy study. Vitreo retinal surgery: Essentials in ophthalmology. 2007;Chapter 5:53-68.

[12] Morris R, Witherspoon CD, Kuhn F, Bryne JB, Endophthalmitis. In: Roy FH (1995) Masters techniques in ophthalmology. Williams and Wilkins, pp 560-572.

[13] Das T, Jalali S, Gothwal V, et al.: Intravitreal dexamethasone in exogenous bacterial endophthalmitis: result of a prospective randomized study. $\mathrm{Br} \mathrm{J}$ Ophthalmol 1999;83:1050-5. 
[14] Clark WL, Kaiser PK, Flynn HW Jr, et al.: Treatment strategies and visual acuity outcomes in chronic postoperative $P$. acnes endophthalmitis. Ophthalmology 1999;106:1665-70.

[15] Aldave AJ, Stein JD, Deramo VA, et al.: Treatment strategies for postoperative Propionibacterium acnes endophthalmitis. Ophthalmology 1999;106:2395-401.

[16] TA: Update on acute and chronic endophthalmitis. Ophthalmology 1999;106:2237-8.

[17] Stern WH, Tamura E, Jacobs RA, et al.: Epidemic postsurgical Candida parapsilosis endophthalmitis: clinical findings and management of 15 consecutive cases. Ophthalmology 1985;92:170.

[18] Petit TH, Olson RJ, Foos RY, et al.: Fungal endophthalmitis following intraocular lens implantation. A surgical epidemic. Arch Ophthalmol 1980;98:1025.

[19] Brinton GS, Topping TM, Hyndiuk RA, et al.: Posttraumatic endophthalmitis. Arch Ophthalmol 1984;102:547.

[20] Thompson JT, Parver LM, Enger C, et al.: Endophthalmitis after penetrating ocular injuries with retained intraocular foreign bodies. Ophthalmology 1993;100:1468.

[21] Vahey JB, Flynn HW Jr: Results in the management of Bacillus endophthalmitis. Ophthalmic Surg 1991;22:681.

[22] Hemady R, Zaltas M, Paton B, et al.: Bacillus-induced endophthalmitis: new series of 10 cases and review of the literature. Br J Ophthalmol 1990;74:26.

[23] Foster RE, Martinez JA, Murray TG, et al.: Useful visual outcomes after treatment of Bacillus cereus endophthalmitis. Ophthalmology 1996;103:390-7.

[24] Thompson JT, Parver LM, Enger C, et al.: Endophthalmitis after penetrating ocular injuries with retained intraocular foreign bodies. Ophthalmology 1993;100:1468.

[25] Wong JS, Chan TK, Lee HM, Chee SP. Endogenous bacterial endophthalmitis: an east Asian experience and a reappraisal of a severe ocular affliction. Ophthalmology 2000;107:1483-91.

[26] Song A, Scott IU, Flynn HWJr, et al.: Delayed-onset bleb-associated endoph-thalmitis: clinical features and visual acuity outcomes. Ophthalmology 2002; 109:985-991.

[27] Busbee BG, Recchia FM, Kaiser R, et al:: Bleb-associated endophthalmitis: clinical characteristics and visual outcomes.Ophthalmology 2004;111:1495-1503.

[28] Nagpal M, Wartikar S, Nagpal K:Comparison of clinical outcomes and wound dynamics of sclerotomy ports of 20, 25, and 23 gauge vitrectomy.Retina 2009 ;29:225-231.

[29] Hilton, George F; Josephberg, Robert G; Halperin, Lawrence S; Madreperla, Steven A; Brinton, Daniel A; Lee, Scott S; et al. Office-Based Sutureless Transconjunctival Pars Plana Vitrectomy. Retina:2002 ;22:725-32.

[30] Tan CS, Wong HK, Yang FP, Lee JJ. Outcome of 23-gauge sutureless transconjunctival vitrectomy for endophthalmitis. Eye. 2008;22:150-1.

[31] Doft BH, Kelsey SF, Wisniewski SR, et al.: Additional procedures after the initial vitrectomy or tap-biopsy in the Endophthalmitis Vitrectomy Study. Ophthalmology, 1998;105:707-16.

[32] Shaarawy A, Meredith TA, Kincaid M, et al. Intraocular injection of ceftazidime. Effects of inflammation and surgery. Retina. 1995;15(5):433-8. 
[33] Huang SS, Brod RD, Flynn HW Jr. Management of endophthalmitis while preserving the uninvolved crystalline lens. Am J Ophthalmol. 1991 15;112:695-701. 


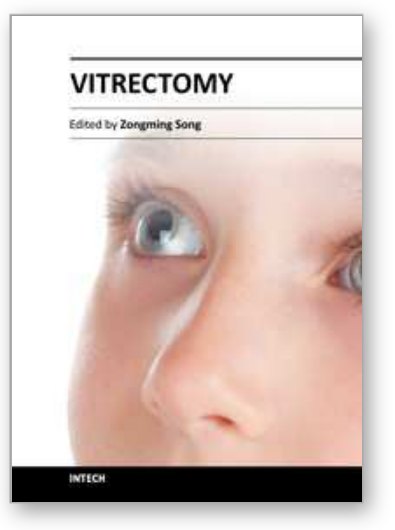

\author{
Vitrectomy \\ Edited by Dr. Zongming Song
}

ISBN 978-953-51-0546-6

Hard cover, 96 pages

Publisher InTech

Published online 20, April, 2012

Published in print edition April, 2012

This book is a comprehensive and systematic introduction to the basic theory, surgical techniques and the latest advances in vitrectomy. It focuses on vitreoretinal surgical indications and contraindications, surgical and operating techniques, surgery-related complications and their prevention, post-operation evaluation and prognosis. The book is divided into 6 chapters and has abundant content as well as a strong scientific and practical value. This book will be a valuable reference to ophthalmologists on all levels, especially vitreoretinal surgeons and researchers.

\title{
How to reference
}

In order to correctly reference this scholarly work, feel free to copy and paste the following:

Kapil Bhatia, Avinash Pathengay and Manav Khera (2012). Vitrectomy in Endophthalmitis, Vitrectomy, Dr. Zongming Song (Ed.), ISBN: 978-953-51-0546-6, InTech, Available from:

http://www.intechopen.com/books/vitrectomy/vitrectomy-for-intraocular-infections

\section{INTECH}

open science | open minds

\author{
InTech Europe \\ University Campus STeP Ri \\ Slavka Krautzeka 83/A \\ 51000 Rijeka, Croatia \\ Phone: +385 (51) 770447 \\ Fax: +385 (51) 686166 \\ www.intechopen.com
}

\author{
InTech China \\ Unit 405, Office Block, Hotel Equatorial Shanghai \\ No.65, Yan An Road (West), Shanghai, 200040, China \\ 中国上海市延安西路65号上海国际贵都大饭店办公楼 405 单元 \\ Phone: +86-21-62489820 \\ Fax: $+86-21-62489821$
}


(C) 2012 The Author(s). Licensee IntechOpen. This is an open access article distributed under the terms of the Creative Commons Attribution 3.0 License, which permits unrestricted use, distribution, and reproduction in any medium, provided the original work is properly cited. 